\title{
Kemampuan Pemecahan Masalah Siswa SMA dalam Menyelesaikan Soal Usaha dan Energi
}

\author{
Aras Hanif Afiat ${ }^{1}$, Supriyono Koes Handayanto ${ }^{1}$, Hari Wisodo ${ }^{1}$ \\ ${ }^{1}$ Pendidikan Fisika-Universitas Negeri Malang
}

\begin{tabular}{l}
\hline INFO ARTIKEL \\
\hline Riwayat Artikel: \\
Diterima: $17-06-2019$ \\
Disetujui: $14-01-2020$ \\
\hline
\end{tabular}

Kata kunci:

problem solving skill; effort and energy; high school student; kemampuan pemecahan masalah; usaha dan energi; siswa SMA

\begin{abstract}
ABSTRAK
Abstract: This study aims to determine the problem solving abilities of high school students in solving physics problem topic working and energy. A total of 64 respondents solved physics problem about work and energy which consisted of four questions. The students' answers were evaluated using a rubric consisting of five indicators, namely useful description (UD), physics approach (PA), specific application of physics (SPA), mathematical procedures (MP), and logical progression (LP). The data analysis technique used qualitative descriptive. The results of the analysis show that the score of students' problem solving abilities is in a sufficient category, with the dominant score on indicators UD, PA and SPA. Students get poor score criteria on MP and LP indicators. In this case, students experience some difficulties, among others, students' mistakes in applying physics concepts in mathematical equations, students' mistakes in using equations that are not relevant to the problems presented and students' mistakes in using calculations that do not focus on the problem presented.
\end{abstract}

\section{Alamat Korespondensi:}

Abstrak: Penelitian ini bertujuan untuk mengetahui kemampuan pemecahan masalah siswa SMA dalam memecahkan persoalan usaha dan energi. Sejumlah 64 responden mengerjakan soal usaha dan energi yang terdiri atas empat soal uraian. Hasil jawaban siswa dikoreksi dengan menggunakan rubrik yang terdiri atas lima indikator, yaitu usefull description (UD), physics approach (PA), spesific application of physics (SPA), mathematical procedures (MP), dan logical progression (LP). Teknik analisis data menggunakan deskriptif kualitatif. Hasil analisis menunjukkan bahwa skor kemampuan pemecahan masalah siswa berada dalam kategori cukup, dengan dominan skor pada indikator UD, PA dan SPA. Siswa mengalami kriteria kurang baik pada indikator MP dan LP. Dalam hal ini, siswa mengalami beberapa kesulitan, antara lain, kesalahan dalam mengaplikasikan konsep dalam persamaan matematis, menggunakan persamaan yang tidak relevan dengan permasalahan yang dipaparkan menggunakan perhitungan yang tidak fokus pada problem yang disajikan.

\author{
Aras Hanif Afiat \\ Pendidikan Fisika \\ Universitas Negeri Malang \\ Jalan Semarang 5 Malang \\ E-mail: aras.hanif.1303216@ students.um.ac.id
}

Kemampuan pemecahan masalah telah menjadi keahlian krusial yang harus dimiliki oleh siswa pada abad ini (Ryan et al. 2016). Hingga saat ini, kemampuan pemecahan masalah dijadikan sebagai tujuan penting yang harus dicapai dalam pendidikan (Ding et al. 2011; Docktor et al. 2010; Seyhan 2014). Para peneliti, khususnya di bidang pendidikan tengah berlomba untuk mencari metode yang cocok dalam meningkatkan kemampuan pemecahan masalah, dan mencari model yang cocok untuk menilai kemampuan pemecahan masalah. Telah banyak metode yang digunakan untuk meningkatkan kemampuan pemecahan masalah, terutama pada bidang fisika (Bing and Redish 2009; De Cock 2012; Docktor et al. 2015; Lin and Singh 2015). Meski demikian, masih terdapat kendala umum yang dihadapi siswa terkait kemampuan pemecahan masalah.

Problematika yang sering dihadapi siswa dalam menyelesaikan permasalahan fisika adalah melakukan plug and chug (Ding et al. 2011; Docktor et al. 2010). Siswa cenderung menyelesaikan permasalahan fisika dengan menerapkan persamaan matematis tanpa memperhatikan prinsip dan konsep yang tepat (Docktor et al. 2015). Padahal, problem solver yang baik harus memahami hakikat konsep dan prinsip yang digunakan untuk menyelesaikan masalah. Oleh sebab itu, penting bagi siswa untuk menyelesaikan permasalahan fisika dengan memperhatikan analisis kualitatif dengan memilah konsep penting (Harun et al. 2012). Kendala menyelesaikan permasalahan fisika juga masih banyak terjadi dalam menyelesaikan persoalan usaha dan energi (Lindsey, Heron, and Shaffer 2012). Materi bahasan usaha dan energi merupakan topik yang abstrak dan kompleks (Desianna Nugroho, Ellianawati, 2019). Untuk memecahkan kasus usaha dan energi, siswa harus memahami konsep sistem dan lingkungan (Serway, Jewett, \& Peroomian, 2014). Selanjutnya, (Lindsey et al. 2012) menjabarkan kesulitan yang dialami siswa dalam menyelesaikan persoalan usaha dan energi, di antaranya (1) kesulitan dalam membedakan sistem dan lingkungan, (2) 
kesulitan dalam memahami sekumpulan objek yang bergerak, dan (3) kesulitan dalam memahami energi konstan dan energi tak konstan. Selain itu, dalam memahami konsep usaha dan energi, siswa juga harus memahami prinsip Hukum Newton dan kinematika. Sebab, kedua prinsip tersebut merupakan prasyarat yang harus dimiliki siswa dalam mempelajari konten usaha dan energi.

Penelitian ini bertujuan untuk menganalisis kemampuan pemecahan siswa dalam memecahkan permasalahan seputar usaha dan energi dengan penilaian menggunakan rubrik yang dikembangkan oleh (Docktor et al. 2016). Fokus penelitian ini adalah untuk menilai proses penyelesaian masalah yang melingkupi pemahaman konsep, aplikasi konsep ke dalam masalah, pemilihan prosedur penyelesaian yang tepat, serta merepresentasikan jawaban dengan runtut dan tepat.

\section{METODE}

Penelitian ini menggunakan teknik analisis deskriptif kualitatif dengan menganalisis jawaban siswa setelah dinilai dengan rubrik proses pemecahan masalah yang dikemukakan oleh (Docktor et al. 2016). Subjek penelitian pada penelitian ini terdiri atas 64 siswa. Pengambilan data dilakukan dengan tes tulis soal usaha dan energi yang terdiri atas empat nomor soal dengan empat kasus yang berbeda. Kasus pertama tentang konsep usaha yang bekerja pada sistem. Siswa diminta untuk mencari usaha pada sistem yang bergerak pada bidang miring. Kasus kedua tentang konsep hubungan antara usaha dan energi potensial. Pada kasus kedua, siswa diminta mencari perubahan energi potensial pada kasus benda jatuh bebas dan mendarat di medium yang berbeda. Kasus ketiga tentang konsep hubungan usaha dan energi kinetik. Siswa diminta untuk menyelesaikan persoalan benda yang mengalami GLBB dengan meninjau besar usaha yang bekerja ataupun yang dikerjakan. Kasus keempat tentang konsep usaha oleh gaya konservatif dan tak konservatif. Dalam hal ini, siswa menyelesaikan problem pada benda jatuh bebas dengan gaya hambat yang bekerja pada sistem. Hasil jawaban siswa dianalisis dengan menggunakan rubrik kemampuan pemecahan masalah yang meliputi lima indikator, yaitu usefull description (UD), physics approach (PA), spesific application of physics (SPA), mathematical procedures (MP), dan logical progression (LP). Kemudian hasil tes dideskripsikan secara kualitatif untuk memperoleh hasil temuan.

\section{HASIL}

Data penelitian diperoleh dari hasil jawaban tes siswa yang terdiri atas empat soal uraian. Jawaban siswa diberi skor dengan mengacu pada rubrik pemecahan masalah. Pemberian skor meliputi lima indikator yang mengukur proses siswa dalam melakukan penyelesaian masalah. Skala skor rubrik memiliki range 0 -5 untuk tiap-tiap indikator.

\section{Konsep Usaha pada Bidang Miring}

Soal pertama adalah kasus sistem yang bergerak pada bidang miring. Dalam persoalan ini, siswa diharuskan untuk mengidentifikasikan besaran dan menggambarkan diagram bebas pada benda yang bergerak pada bidang miring, kemudian mencari besar usaha yang bekerja atau usaha yang dikerjakan sistem. Prinsip yang ditekankan dalam kasus ini adalah cara siswa dalam mengaplikasikan konsep usaha pada lintasan yang membentuk sudut tertentu. Tentunya, hal ini melibatkan pengetahuan siswa mengenai aturan sin dan cos. Dalam hal ini, siswa diharuskan untuk menggambarkan diagram bebas yang memproyeksikan arah gerak gaya yang bekerja pada sistem. Hasil jawaban salah satu siswa dapat dilihat pada gambar 1 .

Gambar 1 menampilkan salah satu hasil jawaban siswa untuk persoalan usaha pada bidang miring. Berdasarkan jawaban siswa, terlihat siswa mampu mendeskripsikan problematika dengan baik. Siswa mampu menyebutkan besaran yang diketahui dan mampu menuliskan diagram gaya. Akan tetapi, dalam menggambarkan proyeksi vektor gaya yang bekerja pada sistem, panjang panah tidak menunjukkan adanya proposionalitas. Hal ini menjadikan kesalahan kecil yang terjadi saat menguraikan komponen vektor gaya. Oleh sebab itu, pada indikator UD, siswa mendapat poin 4 dengan kriteria terdapat sedikit kesalahan.

Pada indikator PA, siswa mampu menyebutkan konsep fisika yang bekerja, yaitu konsep gaya dan usaha. Selain itu, terlihat siswa dapat menjelaskan aplikasi dari konsep tersebut ke dalam permasalahan. Oleh sebab itu siswa mendapat poin lima untuk indikator PA dan SPA. Pada indikator MP, terlihat siswa menggunakan persamaan energi potensial. Meskipun terdapat hay yang tidak konsisten antara PA yang diketahui dengan eksekusi penerapan persamaan, tetapi logika berpikir dalam penyelesaian masalah sudah tepat. Oleh sebab itu, siswa tersebut mendapat poin empat untuk MP dan lima untuk LP. Secara lengkap, hasil rata-rata skor indikator untuk persoalan pertama seluruh responden dapat dilihat pada gambar 2 . 


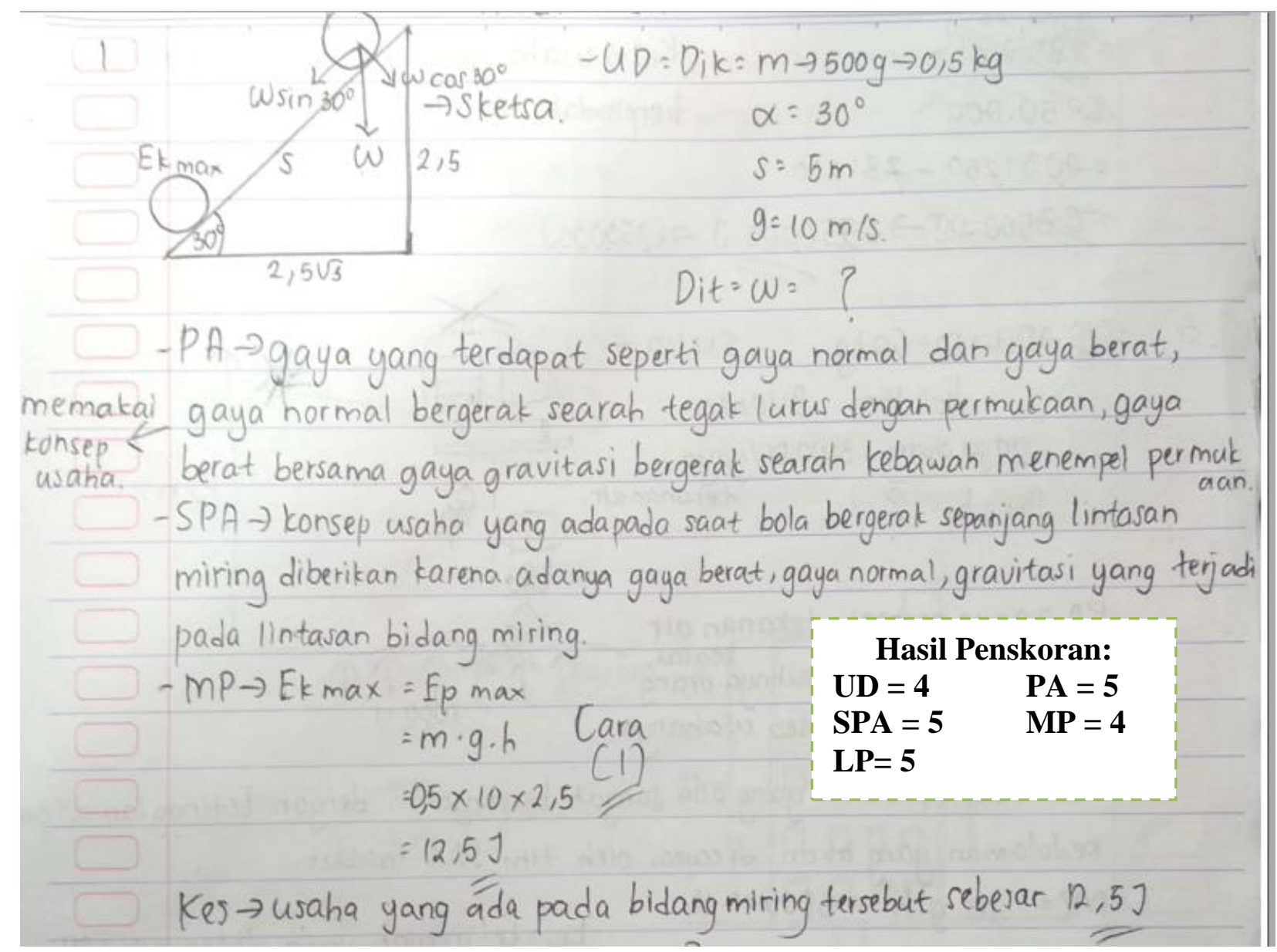

Gambar 1. Salah Satu Hasil Jawaban Soal Pertama

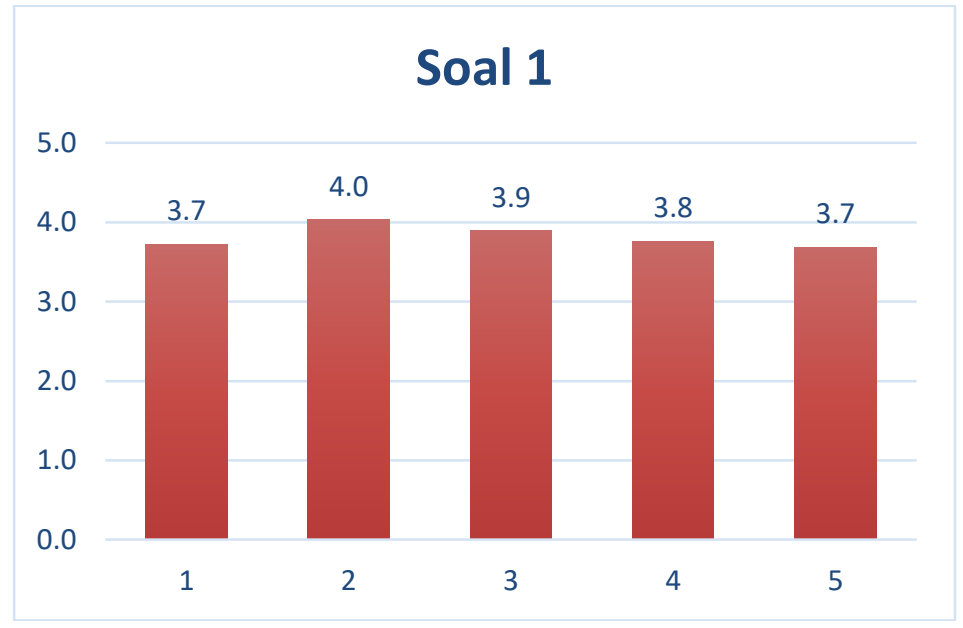

\section{Gambar 2. Skor Kemampuan Pemecahan Masalah Kasus Usaha pada Bidang Miring}

\section{Hubungan Usaha dan Energi Potensial}

Persoalan kedua mengenai konsep hubungan antara usaha dan energi potensial. Pada persoalan ini, siswa diberi permasalahan terkait seseorang yang terjun dari ketinggian tertentu, dan mendarat di area air laut. Siswa diminta mencari hubungan antara energi potensial yang bekerja pada sistem saat bergerak di udara dan usaha yang bekerja pada sistem saat tenggelam di air laut. Salah satu jawaban siswa untuk konsep hubungan antara usaha dan energi kinetik dapat dilihat pada gambar 3 . 
Gambar 3 menampilkan jawaban salah satu siswa secara lengkap. Siswa mampu menuliskan ilustrasi problem dengan baik. Mulai dari menggambar sketsa hingga menuliskan besaran-besaran yang diketahui dalam problem. Oleh sebab itu, siswa mendapat skor lima untuk indikator UD. Selanjutnya, siswa mampu menyebutkan konsep yang bekerja pada problem, serta dapat menuliskan penggunaan penerapan konsep fisika ke dalam permasalahan. Oleh sebab itu, siswa tersebut mendapat poin lima untuk indikator PA dan SPA. Akan tetapi, siswa melakukan kesalahan dalam mengaplikasikan konsep fisika ke dalam persamaan matematis. Berdasarkan jawaban siswa, terlihat bahwa siswa mampu menuliskan hubungan antara usaha dan energi potensial, namun kesalahan terjadi ketika siswa menuliskan gaya yang bekerja pada sistem. Jawaban siswa menampakkan bahwa siswa melewatkan nilai dari gaya berat. Siswa tersebut hanya menuliskan gaya angkat sebagai gaya tunggal yang bekerja pada sistem.

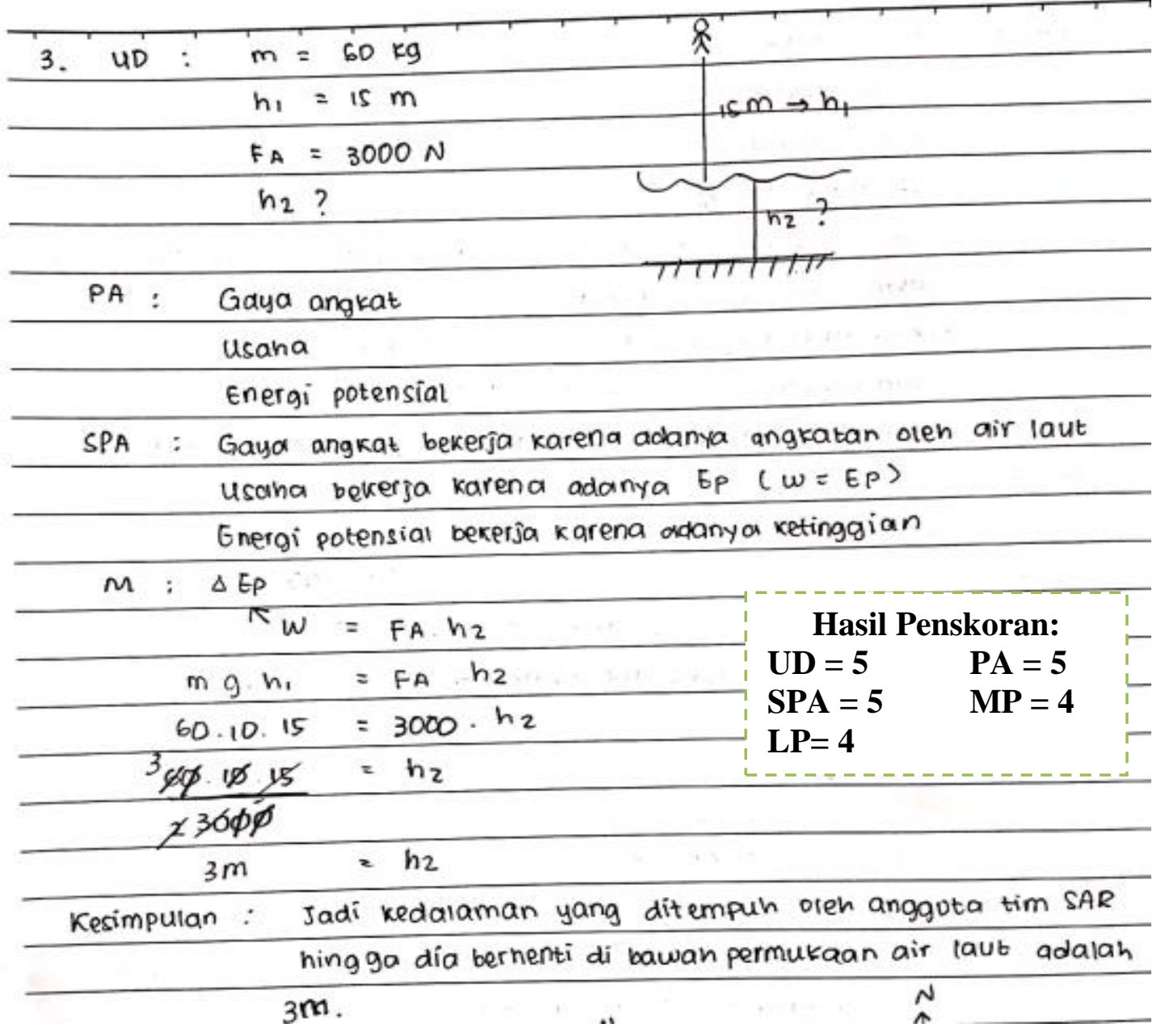

Gambar 3. Salah Satu Jawaban Siswa Soal Kedua

Kesalahan dalam menuliskan gaya yang bekerja akan berakibat fatal pada penulisan hasil. Oleh sebab itu, siswa mendapat poin tiga untuk indikator MP. Poin tersebut memiliki kriteria bahwa terdapat bagian yang terlewatkan dalam menyelesaikan masalah. Secara keseluruhan, logika berpikir dalam menyelesaikan masalah sudah tepat, namun, karena terdapat kesalahan dalam input besaran yang bekerja, maka siswa mendapat poin empat untuk indikator LP. Hasil rata-rata indikator seluruh siswa untuk topik hubungan usaha dan energi dapat dilihat pada gambar 4. Gambar 4 menampilkan bahwa secara keseluruhan kemampuan pemecahan masalah siswa dalam topik hubungan usaha dan energi potensial masih bernilai kurang. 


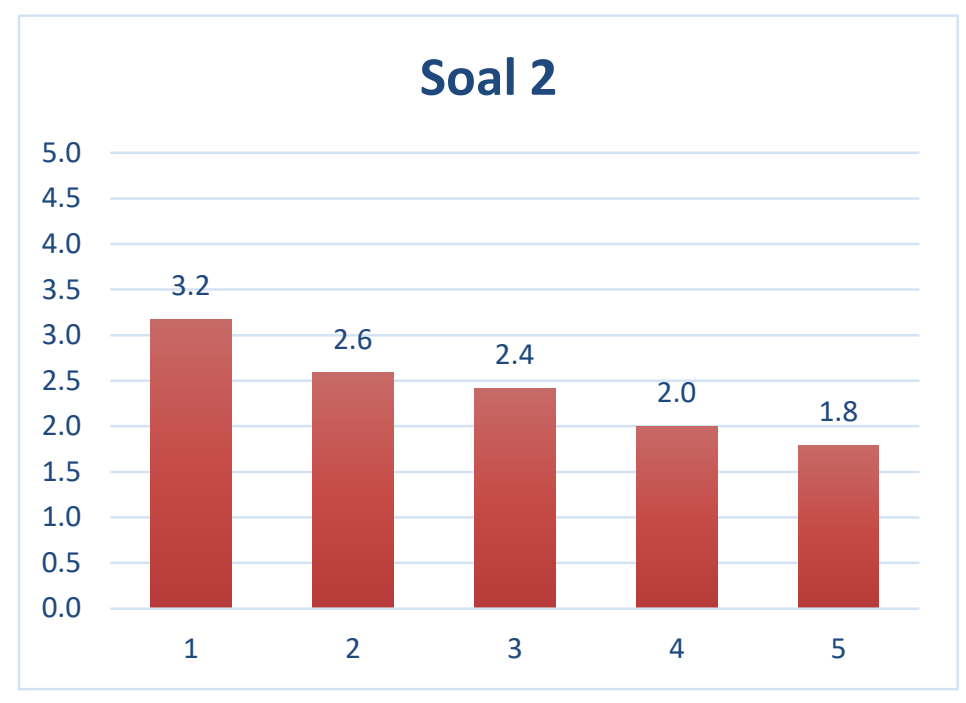

Gambar 4. Skor Kemampuan Pemecahan Masalah Hubungan Usaha dan Energi Potensial

\section{Hubungan Usaha dan Energi Kinetik}

Persoalan ketiga adalah topik mengenai hubungan usaha dan energi kinetik. Pada topik ini, siswa diharuskan untuk mengidentifikasi persoalan benda/sistem yang bergerak secara GLBB. Kemudian siswa mencari besar energi kinetik pada saat kecepatan tertentu. Dalam problem ini, selain mengidentifikasi permasalahan, siswa juga harus dapat mengaitkan prinsip energi kinetik dan usaha yang bekerja pada sistem. Gambar 3 menampilkan salah satu jawaban siswa untuk persoalan hubungan usaha dan energi kinetik.

Gambar 3 menampilkan jawaban salah satu siswa secara lengkap dalam menjawab persoalan dengan topik benda yang bergerak secara GLBB. Dari jawaban tersebut terlihat siswa mampu mengilustrasikan dengan baik gambaran permasalahan yang diketahui di soal. Siswa mampu menggambarkan ilustrasi mobil yang semula bergerak dengan kecepatan tertentu, menginjak pedal hingga akhirnya berhenti. Siswa tersebut juga mampu menuliskan besaran yang diketahui secara tepat. Oleh sebab itu, siswa tersebut mendapat skor lima untuk indikator UD. Pada indikator PA dan SPA memperlihatkan bahwa siswa tersebut mampu menjawab dengan tepat konsep fisika yang bekerja pada permasalahan. Selain itu, siswa tersebut juga dapat mengaplikasikan konsep dengan baik. Oleh sebab itu, siswa jawaban siswa memperoleh poin lima untuk indikator PA dan SPA

Pada penerapan penggunaan persamaan, terlihat bahwa siswa mampu menuliskan hubungan antara usaha dan energi kinetik. Dengan meninjau nilai usaha adalah perubahan energi kinetik dan gaya yang bekerja adalah gaya gesek, maka diperoleh solusi permasalahan yang tepat. Dengan pengerjaan yang runtut, maka jawaban diberi poin lima untuk indikator MP dan LP. Untuk hasil rata-rata skor indikator siswa pada kasus hubungan antara usaha dan energi kinetik dapat dilihat pada gambar 5.

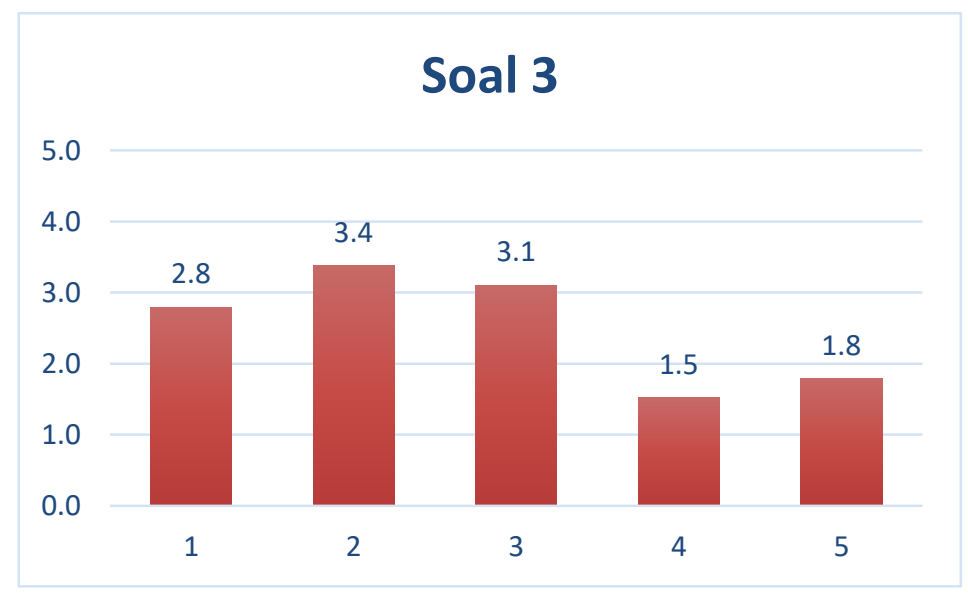

Gambar 5. Skor Kemampuan Pemecahan Masalah Hubungan Usaha dan Energi Kinetik 


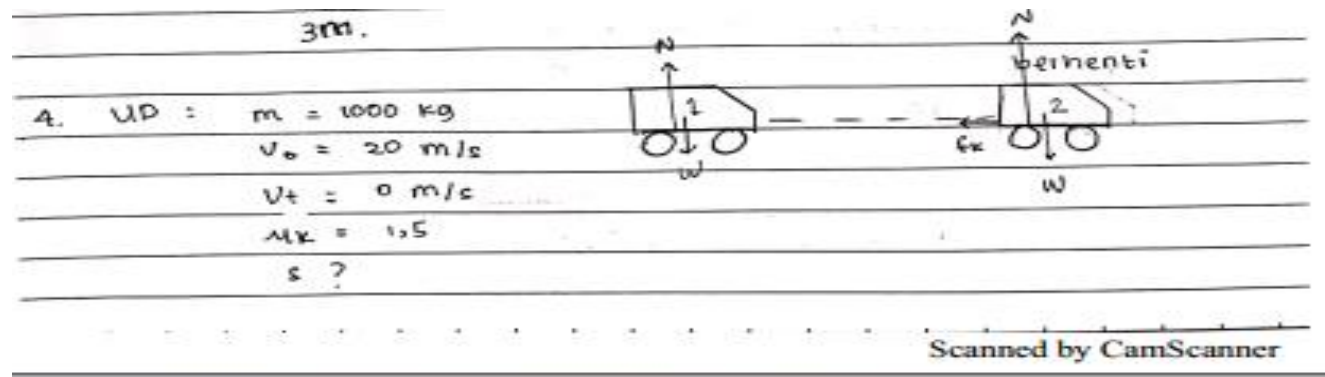

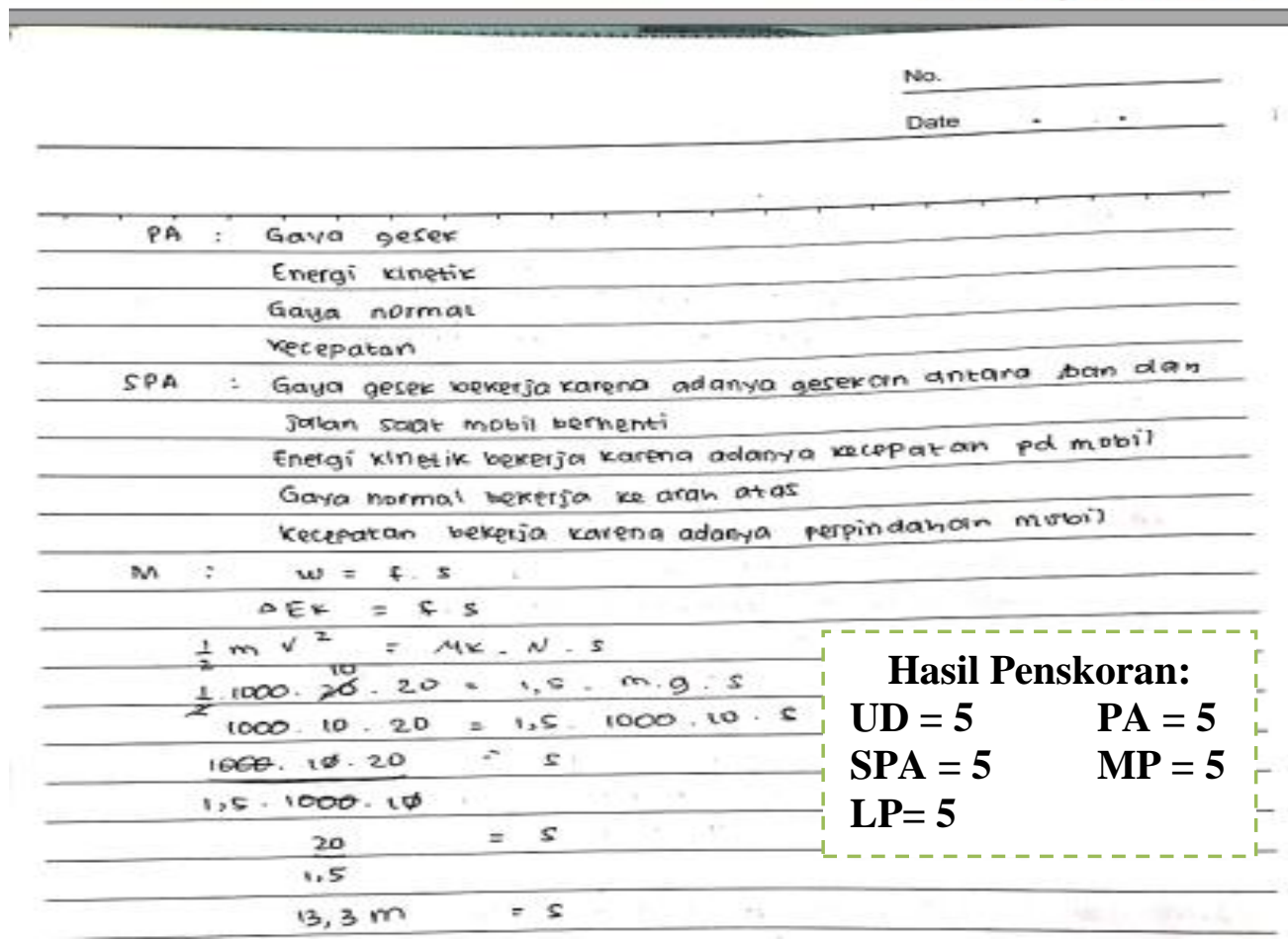

\section{Gambar 6. Salah Satu Jawaban Siswa Soal Ketiga}

\section{Hubungan Usaha dan Energi Mekanik}

Kasus keempat adalah problem yang melibatkan prinsip usaha dan kekekalan energi mekanik. Pada persoalan ini, dipaparkan sebuah sistem/benda yang jatuh di udara. Awalnya, sistem bergerak tanpa gaya hambat. Dalam hal ini, sistem bergerak dengan prinsip hukum kekekalan energi mekanik. Selanjutnya, pada ketinggian tertentu, sistem/benda mendapatkan gaya hambat, sehingga hukum kekekalan energi mekanik tidak berlaku. Dalam keadaan ini, sistem bekerja oleh gaya yang tak konservatif. Hasil salah satu jawaban siswa dapat dilihat pada gambar 4.

Gambar 6 menampilkan jawaban siswa secara lengkap untuk persoalan keempat. Berdasarkan jawaban siswa, terlihat bahwa siswa tersebut mampu menuliskan deskripsi dengan cukup baik dan mampu menyebutkan besaran-besaran yang diketahui. Oleh sebab itu, siswa mendapat poin lima untuk indikator UD. Selanjutnya, siswa juga mampu menyebutkan prinsip yang digunakan, dan aplikasi konsep fisika ke dalam permasalahan. Akan tetapi, terdapat beberapa hal yang terlewatkan. Dalam hal ini, siswa tidak menyebutkan prinsip dari sistem saat bergerak oleh gaya konservatif dan sistem saat bergerak oleh gaya tak konservatif. Oleh sebab itu, siswa mendapat poin empat untuk indikator PA dan SPA, sedangkan pada indikator MP, tampak siswa hanya mampu menjawab benar untuk mencari solusi dari sistem yang bergerak oleh gaya konservatif. Untuk sistem oleh gaya tak konservatif, siswa tidak berhasil menemukan solusi yang tepat. Oleh sebab itu, siswa mendapat poin 3 untuk MP dan 4 untuk LP. 


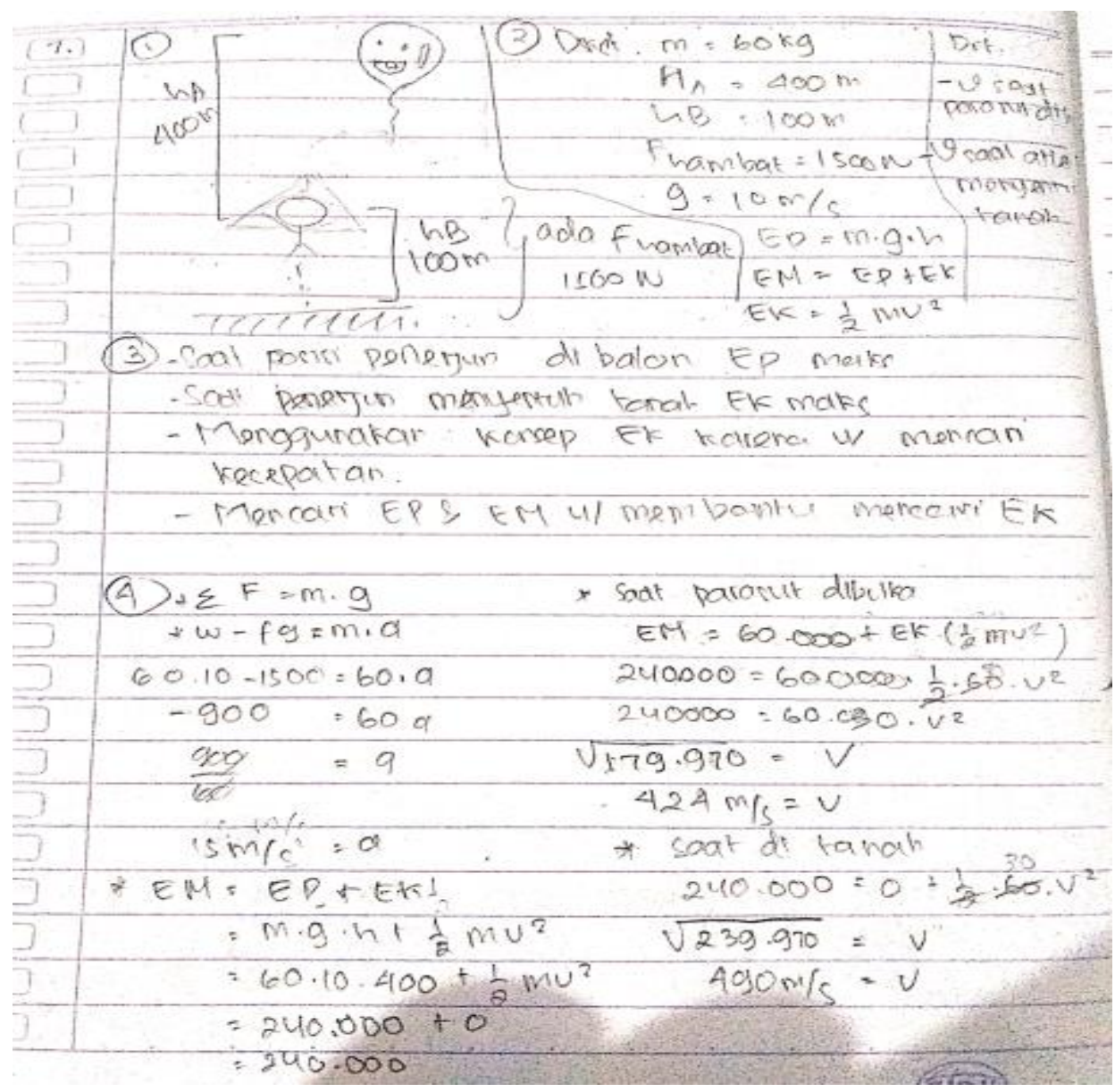

\section{Gambar 7. Salah Satu Jawaban Siswa Soal Keempat}

Pemaparan secara lengkap hasil jawaban siswa terkait permasalahan yang melibatkan hubungan antara usaha dan energi mekanik dapat dilihat pada gambar 8. Diagram tersebut menampilkan rata-rata nilai untuk tiap indikator dari seluruh partisipan yang mengerjakan persoalan keempat. Dari diagram tersebut diperoleh kriteria kemampuan pemecahan masalah untuk permasalahan energi mekanik yang dimiliki siswa masih kurang.

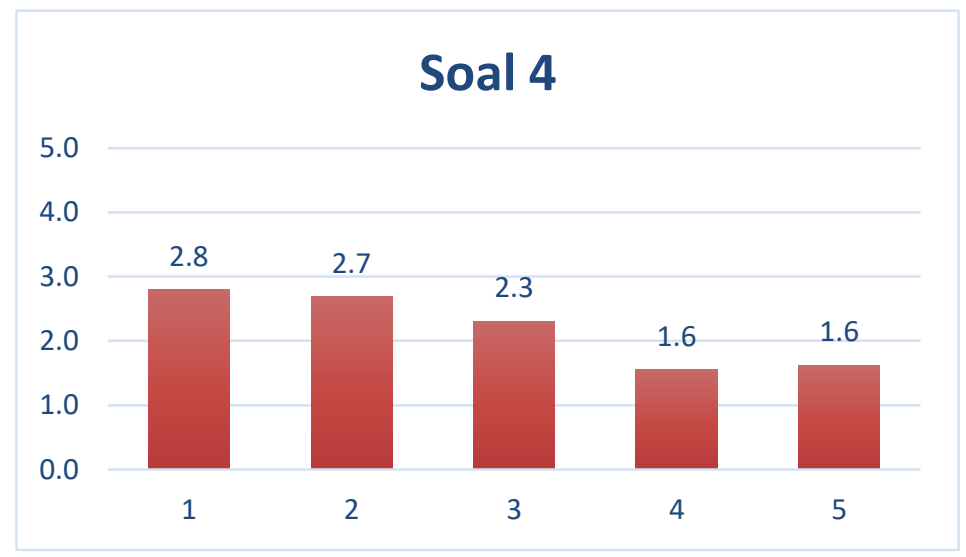

Gambar 8. Skor Kemampuan Pemecahan Masalah Hubungan Antara Usaha dan Energi Mekanik 
Data untuk tiap indikator dijumlah sejumlah banyaknya soal dan jumlah partisipan. Kemudian dicari nilai rata-rata untuk masing-masing indikator kemampuan pemecahan masalah. Data untuk masing-masing indikator merupakan data ordinal yang memiliki range $0-5$. Selanjutnya, hasil rata-rata tiap indikator diklasifikasikan menggunakan skala Likert dengan kategori tidak baik, kurang baik, cukup, baik, dan sangat baik. Skor rata-rata untuk masing-masing indikator seluruh partisipan dapat dilihat pada tabel 1 .

Tabel 1. Deskripsi Skor Indikator Kemampuan Pemecahan Masalah

\begin{tabular}{lcl}
\hline Indikator & Skor Pembulatan & Keterangan \\
\hline Useful Description & 3 & Cukup \\
Physiscs Approach & 3 & Cukup \\
Spesific Application of Physics & 3 & Cukup \\
Matematical Procedures & 2 & Kurang baik \\
Logical Progression & 2 & Kurang baik \\
\hline
\end{tabular}

\section{PEMBAHASAN \\ Konsep Usaha pada Bidang Miring}

Pada persoalan pertama siswa mengerjakan soal yang menerapkan konsep usaha pada bidang miring. Dalam menyelesaikan permasalahan pada kasus ini, siswa harus memahami prinsip hukum newton dan vektor. Termasuk menguraikan gaya-gaya ke dalam sumbu-x maupun sumbu-y. Siswa juga harus bisa menerapkan aturan trigonometri sederhana yang melibatkan sin dan cos. Diagram 1 menampilkan skor tiap indikator yang diperoleh oleh siswa dalam menyelesaikan persoalan pada kasus ini. Siswa memperoleh skor 3,7 untuk indikator usefull description. Itu berarti sebagian besar siswa mampu menuliskan deskripsi permasalahan dengan baik. Meski begitu ada sebagian siswa tidak menjawab dengan sempurna. Kesalahan yang paling banyak terjadi adalah pada penggambaran diagram bebas. Sebagian siswa tidak memproyeksikan arah gaya ke dalam koordinat kartesius. Ada juga siswa yang salah dalam memproyeksikan vektor gaya. Komponen pada sumbu-x, searah lintasan miring yang seharusnya ditulis sebagai F.sin $\alpha$, malah ditulis sebagai F.cos $\alpha$. Padahal, hal ini memengaruhi langkah selanjutnya saat siswa mengaplikasikan konsep ke dalam persamaan matematis.

Kesalahan lain yang dilakukan oleh siswa adalah dalam mengaplikasikan konsep ke dalam persamaan matematis. Kesalahan ini didasari atas kesalahan sebelumnya, di mana siswa menggambarkan komponen vektor gaya secara tidak tepat. Ada juga siswa yang memasukkan persamaan dengan menggunakan rumus dasar, yaitu $W=F C o s \alpha . s$ atau $W=F . s$. Hal ini dikarenakan siswa masih memasukkan persamaan secara acak. Kesalahan ini sebagaimana problematika yang dikemukakan oleh (Ding et al. 2011), dimana siswa menggunakan metode plug and chug untuk menyelesaikan permasalahan fisika.

\section{Hubungan Usaha dan Energi Potensial}

Pada kasus kedua dipaparkan permasalahan yang melibatkan hubungan usaha dan energi potensial. Permasalahan pada kasus ini yaitu seorang benda/sistem yang dijatuhkan di atas ketinggian tertentu, kemudian masuk ke dalam air laut. Dalam hal ini, hubungan usaha dan energi potensial berlaku pada saat sistem jatuh dari ketinggian tertentu hingga tepat di atas di atas permukaan air. Selanjutnya, benda/sistem bergerak menuju kedalaman air hingga titik tertentu, kemudian berhenti dan terangkat ke atas. Dalam hal ini, besar perubahan energi potensial setara dengan energi usaha yang dikerjakan oleh sistem terhadap lingkungan di dalam air laut.

Gambar 2 menampilkan skor rata-rata indikator kemampuan pemecahan masalah. Dari diagram tersebut diperoleh skor tertinggi yaitu indikator usefull description, dengan poin 3,2. Skor ini bahwa sebagian deskripsi sudah fokus menggambarkan permasalahan, tetapi masih ada beberapa bagian yang kurang tepat dan bagian yang terlewatkan. Di sisi lain, indikator lain memiliki skor yang cukup rendah. Pada indikator physics approach, sebagian siswa tidak menuliskan konsep fisika dengan baik. Hal itu menunjukkan sebagian besar siswa masih kurang tepat dalam menuliskan konsep dan prinsip fisika yang bekerja. Ada pula, siswa yang menuliskan konsep yang tidak ada kaitannya dengan hubungan usaha dan energi potensial. Dalam hal ini, siswa meninjau sistem/benda dengan konteks gerak jatuh bebas. Tentunya itu tidak sesuai dengan fokus permasalahan yang disajikan.

Skor mathematical procedures dan logical progression juga berada pada kategori kurang baik. Kesalahan yang terjadi pada saat mengaplikasikan persamaan matematis terjadi pada saat benda/sistem memasuki air laut. Dalam hal ini, gaya yang bekerja pada sistem adalah gaya angkat oleh air laut dan gaya berat. Akan tetapi, sebagian besar siswa melewatkan gaya berat. Kesalahan semacam ini dapat dilihat pada gambar 2. Dari gambar tersebut menampilkan hasil perhitungan matematis siswa yang melewatkan adanya gaya berat. Oleh karena kesalahan tersebut, hasil jawaban tidak sesuai dengan solusi yang semestinya. 


\section{Hubungan Usaha dan Energi Kinetik}

Pada kasus ketiga dipaparkan sebuah sistem/benda yang bergerak lurus berubah beraturan. Suatu sistem yang mulamula bergerak dengan kecepatan awal, memperlambat kecepatannya hingga berhenti. Siswa diminta untuk menghitung perpindahan yang dialami selama sistem selama terjadi perlambatan. Kasus ini mengharuskan siswa menganalisis permasalahan dengan mengaitkan hubungan antara usaha dan energi kinetik. Dalam hal ini, besar usaha setara dengan besar perubahan energi kinetik. Adapun usaha yang bekerja pada sistem adalah usaha oleh gaya gesek.

Gambar 8 memaparkan rata-rata skor untuk masing-masing indikator. Dari pemaparan tersebut, diperoleh skor usefull description berada pada kategori cukup dengan skor 2,8. Hal ini menunjukkan bahwa sebagian besar siswa mengilustrasikan permasalahan secara fokus, namun masih terdapat beberapa hal yang tidak tepat dan terlewatkan. Selanjutnya, meskipun skor physics approach dan spesific application of physics berada pada kriteria cukup, tetapi skor mathematical procedures dan logical progression berada pada kategori rendah. Kriteria tersebut menunjukkan bahwa siswa mampu menuliskan konsep fisika serta mengaplikasikan konsep ke dalam permasalahan. Akan tetapi, siswa kesulitan mengaplikasikan konsep ke dalam persamaan matematis. Kesalahan yang banyak terjadi adalah dalam menghitung usaha oleh gaya gesek. Sebagian besar siswa melewatkan koefisien gaya gesek sehingga gaya yang dimasukkan ke dalam permasalahan bukan gaya gesek, melainkan gaya normal yang setara dengan gaya berat. Hal ini dikarenakan sebagian besar siswa masih menggunakan persamaan secara acak.

\section{Hubungan Usaha dan Energi Mekanik}

Pada kasus keempat dipaparkan permasalahan yang melibatkan energi mekanik, usaha oleh gaya konservatif dan usaha oleh gaya tak konservatif. Permasalahan terjadi pada sistem/benda (dalam hal ini atlet sky diving). Mula-mula atlet bergerak hanya dengan pengaruh gaya berat. Dalam hal ini, berlaku hukum kekekalan energi mekanik. Usaha yang bekerja pada atlet adalah usaha oleh gaya konservatif. Kemudian, pada ketinggian tertentu atlet melepaskan parasut sehingga terdapat gaya hambat yang memengaruhi pergerakan atlet. Dalam hal ini, usaha yang bekerja pada atlet adalah usaha oleh gaya tak konservatif. Siswa diminta untuk mencari kecepatan saat pada ketinggian tertentu sebelum melepaskan parasut, dan mencari kecepatan pada saat siswa mendarat di atas permukaan bumi. Pada kasus kedua, usaha yang bekerja oleh gaya tak konservatif.

Gambar 4 memaparkan skor rata-rata indikator kemampuan pemecahan masalah siswa pada kasus ini. Skor tersebut memperlihatkan indikator usefull description yang dimiliki oleh siswa memiliki kriteria cukup, dengan skor 2,8. Hal ini menunjukkan, sebagian besar siswa pengilustrasian masalah yang ditulis siswa sudah fokus, tetapi masih terdapat beberapa kesalahan dan hal yang terlewatkan. Sebagian besar siswa juga mampu menuliskan konsep yang bekerja dan menerapkan konsep tersebut ke dalam permasalahan, walaupun masih ada kesalahan.

Kesulitan yang dialami oleh siswa adalah pada proses pengimplementasian konsep ke dalam persamaan matematis. Sebagian besar siswa hanya mampu mengerjakan untuk persoalan pada usaha oleh gaya konservatif. Dalam hal ini, siswa menggunakan hukum kekekalan energi mekanik untuk mencari kecepatan pada ketinggian tertentu. Sebagian besar kesulitan yang dialami oleh siswa adalah dalam mengaitkan gaya hambat yang bekerja pada sistem. Siswa kesulitan dalam mengaitkan pengurangan energi mekanik yang setara dengan usaha oleh gaya hambat. Hal ini menunjukkan bahwa siswa masih belum bisa menyelesaikan permasalahan pada kasus usaha yang disebabkan oleh gaya tak konservatif. Hal ini sejalan dengan temuan yang dikemukakan oleh (Lindsey et al. 2012), dimana siswa mengalami kesulitan dalam memahami energi konstan dan energi tak konstan.

\section{SIMPULAN}

Penelitian ini menunjukkan bahwa kemampuan pemecahan masalah yang dimiliki oleh siswa untuk persoalan usaha dan energi berada pada kriteria cukup, untuk indikator usefull description, physics, approach, dan spesific application of physics. Serta, berada pada kriteria kurang baik pada indikator mathematical procedures dan logical progression. Hal ini menunjukkan bahwa siswa masih mengalami kesulitan dalam mengaplikasikan konsep ke dalam persamaan matematis. Hal yang perlu diperhatikan untuk perbaikan selanjutnya adalah menerapkan metode yang tepat dalam mengajar siswa agar siswa terbiasa menerapkan konsep ke dalam persamaan matematis.

\section{DAFTAR RUJUKAN}

Bing, T. J., \& Edward, F. R. (2009). Analyzing Problem Solving Using Math in Physics: Epistemological Framing via Warrants. Physical Review Education Research, 5(2). DOI:https://doi.org/10.1103/PhysRevSTPER.5.020108

De Cock, M. (2012). Representation Use and Strategy Choice in Physics Problem Solving. Physical Review Special Topics Physics Education Research, 8(2). DOI:https://doi.org/10.1103/PhysRevSTPER.8.020117

Desianna, E., Nugroho., S., \& Ellianawati. (2019). Phenomenon of Buying and Selling as Bridging Analogy of Learning Work and Energy. Physics Communication, 3(1), 10-20. DOI: https://doi.org/10.15294/p1hyscomm.v3i1.14921

Ding, L., Reay, N., Lee, A., \& Bao, L. (2011). Exploring the Role of Conceptual Scaffolding in Solving Synthesis Problems. Physical Review Special Topics - Physics Education Research, 7(2), 1-11. 
Docktor, J. L., Dornfeld, J., Frodermann, E., Heller, K., Hsu, L., Jackson, K. A., Mason, A., Ryan, Q. X., \& Yang, J. (2016). Assessing Student Written Problem Solutions: A Problem-Solving Rubric with Application to Introductory Physics. Physical Review Physics Education Research, 12(1), 1-18.

Docktor, J. L., Strand, N. E., Mestre, J. P., \& Ross, B. H. (2015). Conceptual Problem Solving in High School Physics. Physical Review Physics Education Research, 11(2).

Docktor, Jennifer L., Natalie E. Strand, José P. Mestre, Brian H. Ross, Chandralekha Singh, Mel Sabella, and Sanjay Rebello. 2010. A Conceptual Approach to Physics Problem Solving. Pp. 137-40 in. Portland, (Oregon).

Harun, Nor Farida, Khairiyah Mohd Yusof, Mohammad Zamry Jamaludin, and Syed Ahmad Helmi Syed Hassan. (2012). "Motivation in Problem-Based Learning Implementation." Procedia - Social and Behavioral Sciences, 56, $233-42$.

Lin, Shih-Yin., \& Singh, C. (2015). Effect of Scaffolding on Helping Introductory Physics Students Solve Quantitative Problems Involving Strong Alternative Conceptions. Physical Review Education Research, 11(2).

Lindsey, Beth A., Paula R. L. Heron., \& Peter S. Shaffer. (2012). Student Understanding of Energy: Difficulties Related to Systems. American Journal of Physics, 80(2), 154-163.

Ryan, Q. X., Frodermann, E., Heller, K., Hsu, L., \& Mason, A. (2016). Computer Problem-Solving Coaches for Introductory Physics: Design and Usability Studies. Physical Review Physics Education Research, 12(1), 1-17.

Serway, Raymond A., John W. Jewett, and Vahé Peroomian. 2014. Physics for Scientists and Engineers. Ninth Edition. Boston, MA: Cengage Brooks/Cole.

Seyhan, H. G. (2014). The Investigation of the Perception of Problem Solving Skills by Pre-Service Science Teachers in the Science Laboratory. Eurasian Journal Physic \& Chemistry Education, 6(2), 142-161. 